\title{
FAKTOR-FAKTOR YANG MEMPENGARUHI INVESTASI PADA PERUSAHAAN ASURANSI JIWA SYARIAH YANG TERDAFTAR DI OTORITAS JASA KEUANGAN (OJK)
}

\author{
Monica Aprelia Dewi; Zubaidah Nasution; Surya Setiawan \\ Universitas Hayam Wuruk Perbanas Surabaya; Universitas Hayam Wuruk Perbanas \\ Surabaya; Asmi Surabaya \\ e-mail: monicaadewi353@gmail.com; zubaidah@perbanas.ac.id; surya@asmisurabaya.ac.id
}

\begin{abstract}
This research analyzes the effect of tabarru fund and underwriting on investment in sharia life insurance companies in Indonesia that are registered in the Financial Services Authority (OJK). The independent variables are tabarru fund and underwriting. The dependent variable is an investment. The research was conducted using ten companies that met the sample selection criteria of seven years from 2013-2019. The seventy total data are registered with the financial services authority. This research used the purposive sampling technique. The data were analyzed through SPSS as a tool. This study indicated that the tabarru fund had a significant effect on investment in Islamic life insurance companies. Partial analysis ( $t$-test) of tabarru fund had a significant positive impact on investment in Islamic insurance companies for the 2013-2019 period. The simultaneous $F$ significance test results for the tabarru fund and underwriting $F$ significant variables were simultaneously 0.000 less than the 0.05 significance level. Thus it can be concluded that $H_{0}$ was rejected and $H_{1}$ was accepted so that the regression model tested was fit, and the independent variable (tabarru fund and underwriting) simultaneously had affected the dependent variable (investment).
\end{abstract}

Keywords: tabarru fund; underwriting; sharia life insurance company investment

\section{Pendahuluan}

Indonesia merupakan negara muslim terbesar di mana terdapat 229 juta muslim berada di sana. Sebesar 87,2\% dari populasi penduduk Indonesia yang berjumlah 263 juta jiwa atau sekitar $13 \%$ dari populasi muslim dunia. ${ }^{1}$ Sebagai penduduk muslim terbesar, maka keberadaan lembaga keuangan yang sesuai dengan prinsip syariah sangat dibutuhkan, salah satunya adalah asuransi syariah. Menurut Hindarjo, ${ }^{2}$ asuransi merupakan sebuah lembaga keuangan yang bergerak dalam bidang pertanggungan risiko yang pada dasarnya bertujuan untuk membantu masyarakat dalam meminimalisir risiko tertentu di masa mendatang yang tidak diharapkan terjadi, namun tidak hanya untuk kepentingan pribadi dan keluarga melainkan bisa untuk para pelaku usaha untuk meminimalisir risiko kerugian terhadap aset yang dimilikinya. Keberadaan asuransi syariah juga mampu menarik minat masyarakat muslim karena dapat menjangkau kebutuhan masyarakat akan perlindungan terhadap risiko tertentu dengan pengelolaan sesuai dengan syariat Islam.

\footnotetext{
1 https://Ibtimes.Id/Data-Populasi-Penduduk-Muslim-2020-Indonesia-Terbesar-Di-Dunia/, diakses pada 4 Agustus 2020.

2 A. Hindardjo dan Mansuri, 'Pengaruh Dana Tabarru' dan Klaim Terhadap Profitabilitas Pada Perusahaan Asuransi PT. Prudential Unit Syariah Periode 2011-2015”, Jurnal Asy-Syukriyyah, Volume 5, Nomor 1 (2016), 85.
} 
Asuransi syariah di Indonesia lebih dikenal dengan istilah takâful yang berarti saling menanggung atau menanggung bersama. Menurut Fatwa Dewan Syariah Nasional (DSN) Nomor 21/DSNMUI/X/20013 tentang Pedoman Umum Asuransi Syariah, asuransi syariah ( ta 'min, takâful, atau tadämun) adalah usaha saling melindungi dan tolong menolong di antara sejumlah orang atau pihak melalui investasi dalam bentuk aset dan atau tabarru' yang memberikan pola pengembalian untuk menghadapi risiko tertentu melalui akad (perikatan) yang sesuai dengan syariah. Dalam fatwa ini, akad yang dimaksud adalah akad yang tidak mengandung gharär (ketidakjelasan), maysir (perjudian), ribā (bunga), zhulm (penganiayaan), rishwah (suap), barang haram dan maksiat. ${ }^{4}$

Berdasarkan ketentuan-ketentuan di dalam fatwa DSN-MUI tersebut, berbeda dengan asuransi konvensional pada umumnya di mana di dalam asuransi syariah terjadi hubungan kerjasama di antara para pesertanya dengan cara saling menanggung risiko secara bersamasama atau risk sharing dan hak atas surplus underwriting menjadi hak seluruh peserta serta dana kelolaan dan dana investasi dimiliki peserta sesuai dengan akad. Prinsip asas tolong menolong asuransi syariah merupakan dasar dari penerapan asuransi syariah, sesuai yang tertulis dalam al-Quran:

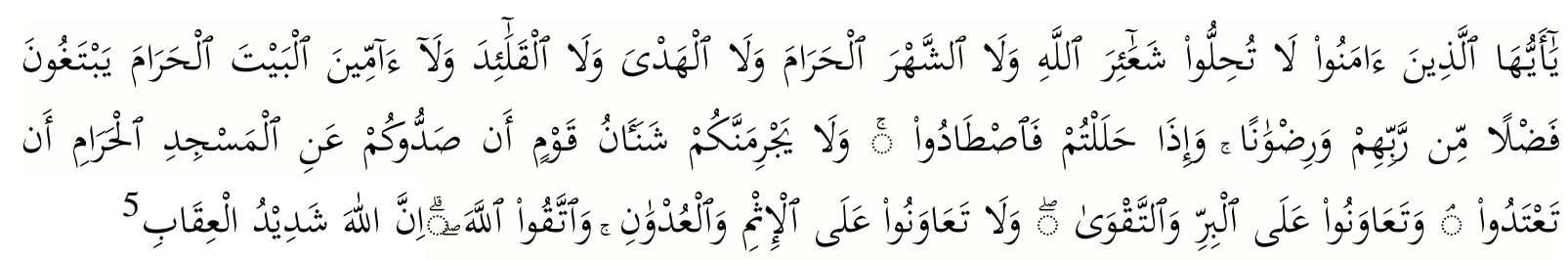

"Dan tolong-menolonglah kamu dalam (mengerjakan) kebajikan dan takwa, dan jangan tolong-menolong dalam berbuat dosa dan pelanggaran, dan bertakwalah kamu kepada Allah. Sesungguhnya Allah amat berat siksa-Nya."

Ayat di atas menjelaskan bahwa dengan asas tolong menolong yang diterapkan, asuransi syariah berperan penting untuk membantu sesame, dalam hal ini dengan meminimalisir risiko yang akan datang dan memberi rasa aman akan ketidakpastian risiko yang akan datang di kemudian hari. Dalam al-Quran, Allah memerintahkan kepada hamba-Nya untuk senantiasa melakukan persiapan untuk menghadapi hari esok, karena itu sebagian dari kita dalam kaitan ini berusaha untuk menabung atau berasuransi. Menabung adalah upaya untuk mengumpulkan dana untuk kepentingan mendesak atau kepentingan yang lebih besar kelak, sedangkan berasuransi untuk berjaga-jaga jika suatu saat musibah itu datang menimpa kita (misalnya kecelakaan, kebakaran dan sebagainya), atau dengan menyiapkan diri jika tulang punggung yang mencari nafkah (suami) di usia tertentu tidak produktif lagi atau ditakdirkan Allah meninggal dunia. Perencanaan akan kehidupan di masa datang tentunya tidak dapat diketahui, akan tetapi Allah menganjurkan umatnya untuk bertakwa dan bekerja sebagai bekal akan kehidupan di masa datang, sebagaimana Allah berfirman dalam al-Quran:

\footnotetext{
${ }^{3}$ Fatwa Dewan Syariah Nasional Nomor 21/DSN-MUI/X/2001 tentang Pedoman Umum Asuransi Syariah.

${ }^{4}$ M. Syakir Sula, Asuransi Syariah (Life And General) (Jakarta: Gema Insani, 2004), 27.

${ }^{5}$ Al-Quran, 5: 2.
} 


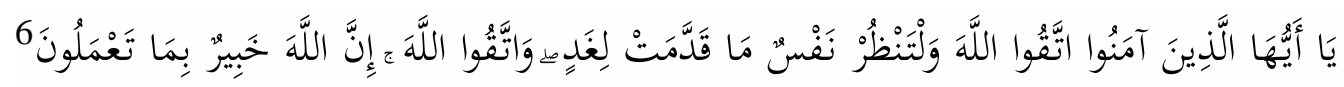

"Hai orang-orang yang beriman, bertakwalah kepada Allah dan hendaklah setiap diri memperhatikan apa yang telah dibuat untuk hari esok (masa depan). Dan bertakwalah kepada Allah sesungguhnya Allah maha mengetahui yang kamu kerjakan”.

Berdasarkan ayat di atas Allah menganjurkan umatnya untuk selalu beriman dan bertakwa, dalam hal ini dapat dilakukan dengan berasuransi syariah yang berasaskan tolong menolong kepada sesama.

Menurut OJK, peran masyarakat dalam berasuransi syariah menunjukan peningkatan. Hal ini dapat dilihat dari data perkembangan asuransi syariah tahun 2013 sampai 2019.

Tabel 1.1. Data Perkembangan Keuangan Asuransi Syariah (Miliar)

\begin{tabular}{|c|c|c|}
\hline Tahun & Investasi & Underwriting \\
\hline 2013 & 16.987 & 316 \\
\hline 2014 & 17.938 & 627 \\
\hline 2015 & 23.070 & 482 \\
\hline 2016 & 28.807 & 350 \\
\hline 2017 & 35.341 & 7.692 \\
\hline 2018 & 36.969 & 6.393 \\
\hline 2019 & 39.846 & 4.525 \\
\hline
\end{tabular}

Sumber: www.ojk.go.id

Berdasarkan tabel di atas, data perkembangan asuransi syariah dari tahun 2013 sampai 2019 mengalami peningkatan. Pada tahun 2013 investasi sebesar 16.987 miliar rupiah dan underwriting sebesar 316 miliar rupiah. Pada tahun 2014 investasi mengalami kenaikan sebesar 17.938 miliar rupiah dan underwriting sebesar 627 miliar rupiah. Tahun 2015 kenaikan investasi hanya sebesar 23.070 miliar rupiah dan underwriting sebesar 482 miliar rupiah. Pada tahun 2016 peningkatan investasi sebesar 28.807 miliar rupiah dengan underwriting yang mengalami penurunan menjadi 350 miliar rupiah. Pada tahun 2017 kenaikan investasi menjadi 35.341 miliar rupiah dan underwriting mengalami peningkatan sebesar 7.692 miliar rupiah. Pada tahun 2018 investasi sebesar 36.969 miliar rupiah, dan underwriting menurun sebesar 6.393 miliar rupiah. Selanjutnya, pada tahun 2019 investasi menunjukkan peningkatan sangat signifikan sebesar 39.846 miliar rupiah dan underwriting menurun sebesar 4.525 miliar rupiah.

Pertumbuhan asuransi syariah setiap tahunnya selalu lebih besar dibandingkan dengan asuransi konvensional. OJK mencatat pertumbuhan industri asuransi sampai tahun 2019 masih positif, memiliki daya tahan yang baik serta tetap memiliki prospek yang besar. Berdasarkan data OJK, sampai akhir tahun 2019 aset IKNB Syariah secara keseluruhan mencapai angka 105,562 triliun rupiah. Penyumbang porsi aset terbesar adalah perasuransian syariah, yaitu 45,45 triliun rupiah atau $43 \%$ dari total aset IKNB Syariah. ${ }^{7}$

\footnotetext{
${ }^{6}$ Ibid, 59: 18.

7 http://www.ojk.go.id/id/DaftarPerusahaan-Asuransi-Umum-Jiwa-dan-Reasuransi-dengan-PrinsipSyariah, diakses pada 4 Agustus 2020.
} 
Asuransi syariah juga mempunyai peran penting sebagai fasilitator hubungan di antara para pesertanya, yaitu tidak hanya mendapatkan perlindungan atas risiko yang dialami akan tetapi peserta akan mendapatkan tabungan beserta keuntungan dari investasi yang dilakukan perusahaan. $^{8}$

Dana tabarru' adalah kumpulan dana yang berasal dari kontribusi para peserta yang mekanisme penggunaannya sesuai dengan akad tabarru' yang disepakati sehingga berpindahnya kepemilikan harta dari pemberi ke yang diberi dan diberikan secara ikhlas dengan mengharap rida Allah kepada sesama peserta asuransi yang mendapatkan musibah. ${ }^{9}$ Dalam pengelolaan dana tabarru' diperlukan proses underwriting. Underwriting merupakan proses yang dilakukan oleh lembaga keuangan untuk menyeleksi dan mengelompokkan risiko yang akan ditanggung oleh peserta. Underwriting sendiri mempunyai tujuan memaksimalkan laba yang didapat melalui penerimaan distribusi risiko yang diperkirakan akan mendatangkan laba. Underwriting merupakan salah satu hal yang penting yang harus diperhatikan oleh perusahaan asuransi syariah, karena tanpa underwriting yang efisien perusahaan asuransi syariah tidak akan mampu bersaing. ${ }^{10}$

Suatu perusahaan asuransi syariah dapat dikatakan mengalami surplus underwriting apabila perusahaan tersebut dapat mengelola dana peserta dengan baik dan dengan adanya hal tersebut dapat menumbuhkan kepercayaan masyarakat bahwa perusahaan asuransi tersebut merupakan perusahaan yang baik. ${ }^{11}$ Menurut Karwati, ${ }^{12}$ surplus underwriting dan dana tabarru' juga dapat digunakan sebagai dana cadangan bagi pembayaran klaim peserta asuransi di masa depan sehingga resiko gagal bayar terhadap klaim dapat diminimalisir.

\section{Metode Penelitian}

Penelitian ini merupakan penelitian kuantitatif, yaitu metode penelitian filsafat positivisme dan metode ilmiah atau scientific yang digunakan untuk data penelitian berupa angka-angka dan analisisnya menggunakan statistik. ${ }^{13}$ Dalam hal ini, penelitian ini bertujuan untuk menganalisis pengaruh dana tabarru' dan underwriting terhadap investasi perusahaan asuransi syariah yang terdaftar di Otoritas Jasa Keuangan (OJK). Sumber data penelitian ini mengunakan data sekunder di mana data yang digunakan berasal dari website laporan keuangan asuransi syariah yang ada di Indonesia. Metode pengumpulan data pada penelitian ini menggunakan penelitian pengamatan karena diterbitkan dari pihak lain yang melihat laporan keuangan perusahaan asuransi syariah. Perusahaan yang digunakan pada penelitian ini menggunakan semua perusahaan asuransi yang terdaftar di Otoritas Jasa Keuangan (OJK) selama periode 2013-2019.

Populasi yang digunakan dalam penelitian ini adalah semua perusahaan asuransi syariah yang ada di Indonesia pada periode 2013-2019. Metode pengambilan sampel yang digunakan

\footnotetext{
${ }^{8}$ A. Hindardjo dan Mansuri, "Pengaruh Dana Tabarru' dan Klaim”, 86.

${ }^{9}$ M. Faozi, "Manajemen Dana Tabarru' Pada Asuransi Takaful Cabang Cirebon", Jurnal Al-Mustashfa, Volume 4, Nomor 2 (2016), 147.

${ }^{10}$ H. Darmawi, Manajemen Asuransi, edisi pertama (Jakarta: PT Bumi Aksara, 2004), 88.

${ }^{11}$ R. Alifianingrum dan N. Suprayogi, Faktor-Faktor yang Mempengaruhi Surplus Underwriting Dana Tabarru”, Jurnal Ekonomi Syariah Teori dan Terapan, Volume 5, Nomor 2 (2018), 149.

${ }^{12}$ Euis Lia Karwati, "Metode Alokasi Surplus Underwriting Dana Tabarru" pada Asuransi Keuangan Syariah" (Skripsi--UIN Syarif Hidayatullah Jakarta, 2011), 78.

${ }^{13}$ S. Siyonto dan A. Sodik, Dasar Metodologi Penelitian, (Yogyakarta: Literasi Media Publishing, 2015), 93.
} 
dalam penelitian ini adalah metode purposive sampling. Purposive sampling adalah teknik pengumpulan sampel dengan kriteria-kriteria atau syarat-syarat yang mempunyai keterkaitan dengan ciri atau sifat populasi yang sudah diketahui. Kriteria yang digunakan pada penelitian ini adalah pertama, perusahaan asuransi jiwa syariah yang terdaftar di Otoritas Jasa Keuangan (OJK) periode 2013-2019, dan kedua, perusahaan asuransi jiwa syariah yang mempublikasikan laporan keuangannya selama tahun 2013-2019 berturut-turut. Adapun nama perusahaan asuransi syariah di Indonesia yang menjadi subyek penelitian adalah PT. Asuransi Jiwa Syariah Al-Amin; PT. Asuransi Jiwa Central Asia Raya; PT. Panin Dai-chi Life; PT. Prudential Syariah; PT. Amanah Jiwa Giri Artha; PT. AIA Financial; PT. Sinar Mas; PT. Axa Financial Indonesia; PT. Asuransi Jiwa Manulife Indonesia; dan PT. Bringin life.

Teknik analisis data yang digunakan dalam penelitian ini adalah analisis deskriptif, yaitu analisis yang digunakan untuk memperoleh gambaran secara umum variabel yang digunakan pada penelitian ini, baik itu variabel independen, yaitu dana tabarru' dan underwriting, maupun variabel dependen, yaitu investasi perusahaan. Selain itu, analisis regresi linear berganda juga digunakan untuk mengetahui seberapa besar pengaruh variabel independen, yaitu dana tabarru' dan underwriting, maupun variabel dependen, yaitu investasi perusahaan.

\section{Asuransi Syariah}

Dana tabarru' merupakan pemberian dana secara sukarela dari para peserta kepada sesama peserta asuransi syariah yang mendapatkan musibah. ${ }^{14}$ Industri asuransi syariah berperan sebagai pengelola premi yang dibayarkan oleh masyarakat yang sebagian besar keuntungan dari hasil investasi tersebut menjadi milik perusahaan kecuali sumber investasi yang berasal dari peserta di mana adanya bagi hasil antara perusahaan dengan peserta sebagaimana yang telah diperjanjikan.

Underwriting merupakan proses yang dilakukan oleh lembaga keuangan untuk menyeleksi dan mengelompokkan risiko yang akan ditanggung atau dicover untuk menentapkan kelayakan calon tertanggung mendapat proteksi dan juga dapat menyesuaikan golongan risiko yang sesuai bagi tertanggung. ${ }^{15}$ Underwriting bertujuan memaksimalkan laba yang didapat melalui penerimaan distribusi risiko yang diperkirakan akan mendatangkan laba. Asuransi akan mendatangkan laba seiring dengan baiknya pengelolaan underwriting di suatu perusahaan asuransi.

Menurut Syakir Sula, ${ }^{16}$ surplus underwriting dana tabarru' diperoleh dari kumpulan dana peserta yang diinvestasikan (insurance fund) kemudian dikurangi dengan biaya-biaya atau beban asuransi seperti reasuransi dan klaim (dana tabarru'). Pada surplus tersebut dibagi hasil antara peserta dan perusahaan sesuai dengan nisbah yang telah ditentukan perolehan bagian perusahaan diambil sebagai biaya operasional sebelum menjadi profit perusahaan. Dalam penelitihan yang dilakukan oleh Sastri $^{17}$ disimpulkan bahwa hasil underwriting berpengaruh terhadap laba perusahaan asuransi di mana peningkatan hasil underwriting maka

\footnotetext{
${ }^{14}$ M. Syakir Sula, Asuransi Syariah, 36.

${ }^{15}$ Ali Hasan, Asuransi dalam Perspektif Hukum Islam (Jakarta: Prenada Media, 2004), 129.

${ }^{16}$ M. Syakir Sula, Asuransi Syariah, 38.

${ }^{17}$ I. Sastri, dkk, "Pengaruh Pendapatan Premi, Hasil Underwriting, Hasil Investasi, dan Risk Based Capital Terhadap Laba Perusahaan Asuransi”, Jurnal Jurusan Akuntansi, Volume 7, Nomor 1 (2017), 72.
} 
laba asuransi akan meningkat. Hal ini menunjukkan pendapatan underwriting suatu perusahaan asuransi mampu menutupi semua beban underwriting sehingga ada kelebihan dana yang dinamakan hasil underwriting. Hasil underwriting yang tinggi akan mempengaruhi besarnya laba pada perusahaan asuransi.

Investasi merupakan instrumen pengelolaan dana yang dilakukan oleh perusahaan asuransi syariah dengan tujuan agar investasi tersebut dapat mendapatkan keuntungan, akan tetapi di dalam asuransi syariah investasi tidak bisa dilakukan pada berbagai kegiatan usaha yang bertentangan dengan prinsip syariah dan mengandung unsur haram dalam kegiatannya. Asuransi jiwa syariah melakukan portofolio investasi untuk mendapatkan hasil optimal dengan meminimalkan risiko yang ada. Keuntungan dari hasil investasi tersebut menjadi milik perusahaan kecuali sumber investasi berasal dari peserta maka dilakukan bagi hasil antara perusahaan dengan peserta sebagaimana yang telah diperjanjikan. ${ }^{18}$

Perusahaan asuransi pada dasarnya memiliki kebutuhan penghasilan investasi yang tinggi dari aset-aset investasi yang mereka miliki. Pengelolaan investasi yang baik akan dapat mengakomodasi tingkat resiko investasi yang dapat ditoleransi oleh perusahaan dengan hasil investasi yang sesuai yang pada akhirnya dapat meningkatkan kinerja laba-rugi perusahaan. ${ }^{19}$ Berdasarkan hasil penelitian Nasution, ${ }^{20}$ investasi berpengaruh positif dan signifikan terhadap pertumbuhan aset asuransi syariah. Artinya semakin tinggi hasil investasi yang diperoleh perusahaan, maka dapat memberikan sebuah sinyal positif bahwa di perusahaan memiliki kinerja yang baik di masa yang akan datang.

\section{Uji Koefisien Determinasi}

Penelitian ini bertujuan untuk mengetahui apakah dana tabarru' dan underwriting berpengaruh terhadap investasi perusahaan asuransi syariah untuk periode 2013-2019. Pada penelitian ini terdapat 10 sampel perusahaan yang sesuai dengan kriteria dalam pemilihan sampel. Koefisien determinasi digunakan untuk menjelaskan seberapa besar kontribusi pengaruh yang diberikan variabel dependent secara simultan terhadap variabel independent. Kapabilitas model dapat dikatakan semakin baik jika nilai Adjusted R square yang dihasilkan mendekati angka 1. Hasil dari uji koefisien determinasi terhadap model regresi pada penelitian ini disajikan dalam tabel.

Tabel 1.2. Hasil Analisis Uji Koefisien Determinasi $\left(\mathrm{R}^{2}\right)$

\begin{tabular}{|l|l|l|l|l|}
\hline Model & R & R. Square & $\begin{array}{l}\text { Adjusted R } \\
\text { Square }\end{array}$ & $\begin{array}{l}\text { Std. Error of } \\
\text { the Estimate }\end{array}$ \\
\hline 1 & .949 & .901 & .899 & 83764.053 \\
\hline
\end{tabular}

Sumber : Hasil output SPSS, data diolah

Berdasarkan hasil uji koefesien determinasi nilai Adjusted $R$ Square sebesar 89,9\%. Hal ini menunjukkan bahwa variabel independen yang digunakan dalam model penelitian ini

\footnotetext{
18 Abdullah Amrin, Asuransi Syariah (Keberadaan dan Kelebihannya di Tengah Asuransi Konvensional) (Jakarta: PT Elex Media Komputindo, 2006), 94.

${ }^{19}$ I. Sastri, dkk, "Pengaruh Pendapatan Premi", 73.

20 Z. Nasution dan E. Sistiyarini, "Determinan Pertumbuhan Aset Asuransi Syariah di Indonesia", Jurnal Masharif Al-Syariah, Volume 4, Nomor 1 (2019), 58.
} 
cukup baik, yaitu $89,9 \%$ sedangkan sisanya $10,1 \%$ dipengaruhi oleh variabel lain di luar variabel yang digunakan.

\section{Uji Simultan (Uji F)}

Uji simultan (uji F) bertujuan untuk melihat pengaruh varuabel independen terhadap variable dependen secara simultan. Jika nilai Sig. $<0.05$ atau nilai $\mathrm{F}$ hitung $>\mathrm{F}$ tabel, maka artinya variabel independent secara simultan berpengaruh terhadap variabel dependent. Sebaliknya, apabila nilai Sig. > 0.05 atau nilai F hitung < F tabel, maka artinya variabel independent secara simultan tidak berpengaruh terhadap variabel dependent. Hasil uji simultan (Uji F) dapat dilihat dalam tabel.

Tabel 1.3. Hasil Analisis Uji F

\begin{tabular}{|l|r|r|r|r|r|}
\hline \multicolumn{1}{|c|}{ Model } & Sum Squares & \multicolumn{1}{c|}{ Df } & $\begin{array}{c}\text { Mean } \\
\text { Square }\end{array}$ & F & Sig. \\
\hline $1 \quad$ Regression & $4.303 \mathrm{E} 12$ & 2 & $2.151 \mathrm{E} 12$ & 306.593 & .000 \\
\hline Residual & $4.701 \mathrm{E} 11$ & 67 & $7.016 \mathrm{E} 9$ & & \\
\hline Total & $4.772 \mathrm{E} 12$ & 69 & & & \\
\hline
\end{tabular}

Sumber : Hasil output SPSS, data diolah

Berdasarkan hasil uji siginifikansi $\mathrm{F}$ secara simultan, variabel dana tabarru' dan underwriting siginifikansi $\mathrm{F}$ secara simultan 0.000 lebih kecil dari taraf signifikansi 0.05 , dengan demikian dapat disimpulkan bahwa $\mathrm{H} 0$ ditolak dan $\mathrm{H} 1$ diterima, sehingga model regresi yang diujikan adalah fit dan variabel independen (dana tabarru' dan underwriting) secara simultan memiliki pengaruh terhadap variabel dependen (investasi).

\section{Analisis Regresi Linear Berganda}

Uji statistik $\mathrm{t}$ digunakan untuk mengetahui apakah variabel bebas atau independen (X) secara parsial berpengaruh terhadap variabel terikat atau variabel dependen (Y). Ketentuan penerimaan atau penolakan hipotesis penelitian adalah dengan membandingkan nilai sig. $\mathrm{t}$ dengan signifikansi a sebesar 0.05. Kesimpulan $\mathrm{H} 0$ ditolak jika nilai sig. t lebih kecil atau sama dengan 0.05 maka dengan demikian H1 diterima. Sedangkan, jika nilai sig. t lebih besar dari 0.05 berarti $\mathrm{H} 0$ diterima.

Tabel 1.4. Hasil Analisis Regresi Linear Berganda

\begin{tabular}{|l|r|r|r|r|r|}
\hline \multirow{2}{*}{ Model } & \multicolumn{2}{|c|}{$\begin{array}{c}\text { Unstandardized } \\
\text { Coefficients }\end{array}$} & \multicolumn{1}{c|}{$\begin{array}{c}\text { Standardized } \\
\text { Coefficients }\end{array}$} & \multirow{2}{*}{$\mathrm{T}$} & \multirow{2}{*}{ sig } \\
\cline { 2 - 4 } & \multicolumn{1}{|c|}{ B } & \multicolumn{1}{c|}{ Std. Error } & \multicolumn{1}{c|}{ Beta } & & \\
\hline 1 (constant) & 13854.295 & 10614466 & & 1.305 & .1696 \\
\hline Dana tabarru' & .050 & .004 & .897 & 12.327 & .000 \\
\hline Underwriting & .020 & .023 & .061 & 5.752 & .401 \\
\hline
\end{tabular}

Sumber : Hasil output SPSS, data diolah

Pada tabel di atas, persamaan regresi pada nilai konstan sebesar 13854.295 di mana hal ini menunjukkan bahwa jika seluruh variabel independen, yaitu dana tabarru' dan 
underwriting dianggap konstan, maka nilai investasi sebesar 13854.295. Koefisien variabel dana tabarru' sebesar 0.050 dengan arah hubungan positif menunjukkan bahwa ketika dana tabarru' naik satu satuan maka investasi juga akan mengalami peningkatan sebesar 0.050. Dari hasil uji t yang telah dilakukan diperoleh hasil sig sebesar $0.00<0.05$. Hal ini dapat diartikan bahwa H0 ditolak dan H1 diterima. Dengan kata lain, bahwa dana tabarru' berpengaruh positif signifikan terhadap investasi pada perusahaan asuransi. Berdasarkan hasil analisis regresi menunjukkan bahwa dana tabarru' memiliki nilai koefisien 0.05. Artinya, dana tabarru' berpengaruh positif terhadap investasi serta setiap kenaikan satu satuan dana tabarru' akan menaikkan investasi sebesar 0.050. Hasil pengujian hipotesis dalam tabel uji parsial (uji t) menunjukkan bahwa secara parsial dana tabarru' berpengaruh signifikan terhadap investasi sehingga hipotesis penelitian ini diterima.

Hal ini mengidentifikasikan bahwa dana tabarru' tidak menentu dapat dipengaruhi oleh beberapa factor, seperti tingkat pemasaran atau tingkat penjualan dan persaingan. Menurut fatwa Dewan Syariah Nasional Nomor 53/DSN-MUI/III/2006 tentang Akad Tabarru' pada Perusahaan Asuransi Syariah, investasi diperlukan untuk mengelola dana tabarru' peserta agar apabila tidak ada klaim dana tersebut tidak menganggur begitu saja, namun dapat digunakan untuk berinvestasi dan mendapatkan keuntungan di masa yang akan datang dan hasil investasinya bisa dibagi antara peserta dan perusahaan sesuai dengan yang disepakati pada akad. Hasil dari penelitian ini didukung oleh hasil dari penelitian terdahulu yang dilakukan oleh Hindardjo ${ }^{21}$ yang menyatakan bahwa dana tabarru' mempunyai nilai pengaruh yang besar secara parsial. Menurutnya, semakin tinggi premi, maka laba yang diperoleh semakin besar.

Koefisien variabel underwriting sebesar 0.020 dengan arah hubungan positif menunjukkan bahwa ketika underwriting naik satu satuan, maka investasi juga akan mengalami peningkatan sebesar 0.020. Dari hasil uji t yang telah dilakukan diperoleh hasil sig sebesar $0.401>0.05$. Hal ini dapat diartikan bahwa H0 diterima dan H1 ditolak. Dengan kata lain bahwa underwriting tidak signifikan terhadap investasi pada perusahaan asuransi jiwa syariah. Berdasarkan hasil analisis regresi menunjukkan bahwa underwriting memiliki nilai koefisien 0.020. Artinya, underwriting tidak berpengaruh terhadap investasi pada perusahaan asuransi jiwa syariah serta setiap kenaikan satu satuan dana tabarru' akan menaikkan investasi sebesar 0.020. Hasil pengujian hipotesis pada tabel uji parsial (uji t) menunjukkan bahwa secara parsial underwriting tidak berpengaruh signifikan terhadap investasi sehingga hipotesis penelitian ini ditolak.

Underwriting merupakan proses pengelompokkan dan penyeleksian risiko yang akan di tanggung oleh peserta. Underwriting di sini mempunyai tujuan memaksimalkan laba yang didapat melalui penerimaan distribusi risiko yang diperkirakan akan mendatangkan laba. Ketika pendapatan underwriting pada perusahaan asuransi mampu menutupi semua beban underwriting yang meliputi komisi tanggungan sendiri, klaim tanggungan sendiri dan kenaikan atau penurunan estimasi klaim tanggungan sendiri, maka akan ada kelebihan dana yang dinamakan hasil underwriting di mana hasil underwriting yang tinggi akan mempengaruhi besarnya laba perusahaan asuransi.

\footnotetext{
${ }^{21}$ A. Hindardjo dan Mansuri, "Pengaruh Dana Tabarru' dan Klaim”, 88.
} 
Hal ini mengidentifikasikan bahwa hasil underwriting yang tinggi pada perusahaan asuransi secara umum menunjukkan baiknya proses underwriting yang telah dilakukan, sedangkan penurunan hasil underwriting menunjukkan semakin memburuknya kinerja underwriting selama periode tertentu. Namun apabila perusahaan tersebut berhasil mengelola dana peserta dengan baik dan dengan adanya surplus underwriting maka akan menumbuhkan kepercayaan masyarakat bahwa perusahaan asuransi tersebut termasuk perusahaan yang baik. Surplus underwriting dana tabarru' juga dapat digunakan sebagai cadangan bagi pembayaran klaim peserta asuransi di masa depan sehingga risiko gagal bayar terhadap klaim dapat diminimalisir. Hasil dari penelitian ini didukung oleh hasil dari penelitian terdahulu yang dilakukan oleh Sari $^{22}$ yang menyatakan bahwa hasil underwriting tidak berpengaruh terhadap laba perusahaan asuransi yang terdaftar di Bursa Efek Indonesia.

\section{Kesimpulan}

Dari pembahsan di atas, maka dapat disimpulkan bahwa pertama, dana tabarru' berpengaruh positif signifikan terhadap investasi perusahaan asuransi syariah periode 20132019. Hal tersebut disebabkan oleh tingkat kepercayaan nasabah dalam menginvestasikan dananya untuk menjamin risiko yang akan datang tinggi, sehingga pendapatan dana tabarru' menjadi maksimal. Underwriting tidak signifikan terhadap investasi perusahaan asuransi syariah periode 2013-2019. Hal tersebut disebabkan oleh perusahaan belum mampu mengelompokkan risiko dalam memenuhi kewajibannya, seperti pembayaran klaim dan modal yang dibutuhkan oleh perusahaan dalam menghadapi risiko, sehingga calon nasabah belum tertarik dengan perusahaan asuransi syariah karena dirasa kesehatan keuangan perusahaan belum cukup baik. Pada kinerja kesehatan keuangan yang baik, maka akan meningkatkan image perusahaan tersebut karena pihak eksternal hanya mampu menilai dari sisi kinerja yang nyata.

Kedua, berdasarkan hasil uji siginifikansi F secara simultan, variabel dana tabarru' dan underwriting siginifikansi $\mathrm{F}$ secara simultan 0.000 lebih kecil dari taraf signifikansi 0.05 , dengan demikian dapat disimpulkan bahwa $\mathrm{H} 0$ ditolak dan $\mathrm{H} 1$ diterima, sehingga model regresi yang diujikan adalah fit dan variabel independen (dana tabarru' dan underwriting) secara simultan memiliki pengaruh terhadap variabel dependen (investasi).

\section{Daftar Rujukan}

Alifianingrum, R. dan N. Suprayogi. Faktor-Faktor yang Mempengaruhi Surplus Underwriting Dana Tabarru", Jurnal Ekonomi Syariah Teori dan Terapan, Volume 5, Nomor 2 (2018).

Amrin, Abdullah. Asuransi Syariah (Keberadaan dan Kelebihannya di Tengah Asuransi Konvensional). Jakarta: PT Elex Media Komputindo, 2006.

Darmawi, H. Manajemen Asuransi, edisi pertama. Jakarta: PT Bumi Aksara, 2004.

Faozi, M. "Manajemen Dana Tabarru' Pada Asuransi Takaful Cabang Cirebon", Jurnal AlMustashfa, Volume 4, Nomor 2 (2016).

Fatwa Dewan Syariah Nasional Nomor 21/DSN-MUI/X/2001 Tentang Pedoman Umum

\footnotetext{
${ }^{22}$ M. A. Sari, dkk, "Analisis Pengaruh Hasil Investasi, Hasil Underwriting dan Beban Klaim Terhadap Laba Perusahaan”, Jurnal Ekonomi dan Kewirausahaan, Volume 19, Nomor 4 (2019), 533.
} 
Asuransi Syariah.

Hasan, Ali. Asuransi dalam Perspektif Hukum Islam. Jakarta: Prenada Media, 2004.

Hindardjo, A. dan Mansuri. "Pengaruh Dana Tabarru' dan Klaim Terhadap Profitabilitas Pada Perusahaan Asuransi PT. Prudential Unit Syariah Periode 2011-2015”, Jurnal AsySyukriyyah, Volume 5, Nomor 1 (2016).

Karwati, Euis Lia. "Metode Alokasi Surplus Underwriting Dana Tabarru"e pada Asuransi Keuangan Syariah”, Skripsi--UIN Syarif Hidayatullah Jakarta, 2011.

Nasution, Z. dan E. Sistiyarini. "Determinan Pertumbuhan Aset Asuransi Syariah di Indonesia”, Jurnal Masharif Al-Syariah, Volume 4, Nomor 1 (2019).

Sari, M. A. dkk. "Analisis Pengaruh Hasil Investasi, Hasil Underwriting dan Beban Klaim Terhadap Laba Perusahaan”, Jurnal Ekonomi dan Kewirausahaan, Volume 19, Nomor 4 (2019).

Sastri, I., dkk. "Pengaruh Pendapatan Premi, Hasil Underwriting, Hasil Investasi, dan Risk Based Capital Terhadap Laba Perusahaan Asuransi”, Jurnal Jurusan Akuntansi, Volume 7, Nomor 1 (2017).

Siyonto, S. dan A. Sodik. Dasar Metodologi Penelitian. Yogyakarta: Literasi Media Publishing, 2015.

Sula, M. Syakir. Asuransi Syariah (Life And General). Jakarta: Gema Insani, 2004.

https://Ibtimes.Id/Data-Populasi-Penduduk-Muslim-2020-Indonesia-Terbesar-Di-Dunia/, diakses pada 4 Agustus 2020.

http://www.ojk.go.id/id/DaftarPerusahaan-Asuransi-Umum-Jiwa-dan-Reasuransi-denganPrinsipSyariah, diakses pada 4 Agustus 2020. 